Section Editor

Mitchell S.V. Elkind, MD, MS

\title{
Teaching NeuroImages: \\ Neurodegeneration with brain iron accumulation in aceruloplasminemia
}

Natalie E. Parks, MD Robert A. Vandorpe, MD Jeremy J. Moeller, MD

Correspondence to

Dr. Moeller:

jeremy.moeller@yale.edu

\section{Figure 1 Brain iron accumulation in aceruloplasminemia}

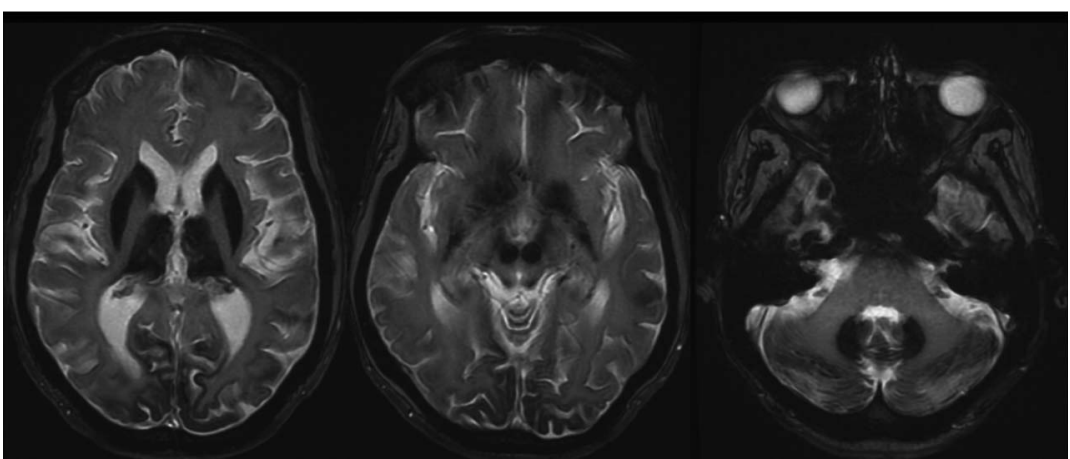

Axial T2-weighted gradient echo MRI demonstrates hypointensity of the caudate nuclei, putamina, thalami, red nuclei, occipital cortex, and cerebellar dentate nuclei consistent with brain iron accumulation.

Figure 2 Hepatic iron accumulation in aceruloplasminemia

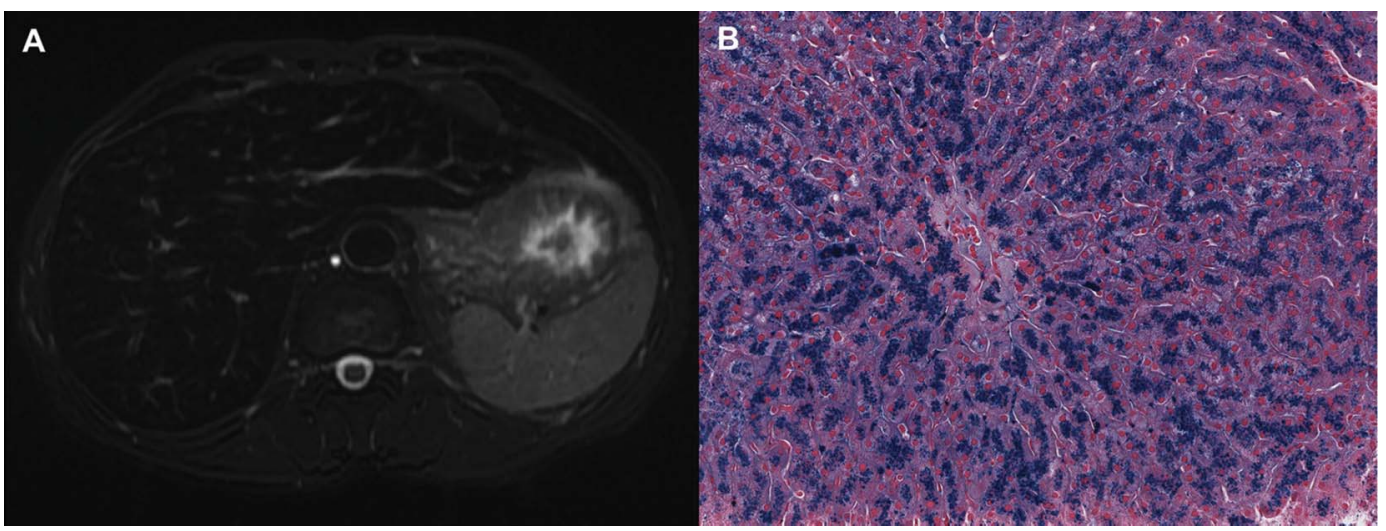

(A) Axial T2-weighted MRI demonstrates hypointense liver parenchyma consistent with hepatic iron accumulation. (B) Liver needle biopsy with Prussian blue histochemical stain demonstrates increased hepatocyte iron stores (40× equivalent).

A 55-year-old African Canadian man with insulindependent diabetes mellitus and alcohol abuse presented with diabetic ketoacidosis. Progressive cognitive decline over the previous 5 years resulted in long-term care placement. Aside from pigmentary retinopathy, general examination was unremarkable. MRI demonstrated iron accumulation in the brain (figure 1) and liver (figure 2A). Ceruloplasmin, a ferroxidase enzyme important in iron homeostasis, was undetectable and associated with low serum iron, low serum copper, and 10-fold increase in serum ferritin. Liver biopsy confirmed increased hepatocyte iron storage (figure 2B). Aceruloplasminemia was diagnosed. ${ }^{1,2}$ Iron chelation was not administered given advanced dementia at presentation.
Download teaching slides: www.neurology.org 


\section{AUTHOR CONTRIBUTIONS}

Natalie E. Parks analyzed and interpreted material for inclusion in this case report and drafted and revised the manuscript. Robert A. Vandorpe analyzed and interpreted material for inclusion in this case report and revised the manuscript. Jeremy J. Moeller analyzed and interpreted material for inclusion in this case report and revised the manuscript.

\section{ACKNOWLEDGMENT}

Photomicrograph courtesy of Dr. Erica Schollenberg (Department of Pathology, Dalhousie University, Halifax, Nova Scotia, Canada).

\section{STUDY FUNDING}

No targeted funding reported.

\section{DISCLOSURE}

N. Parks and R. Vandorpe report no disclosures. J. Moeller has received speaker's fees from EMD, Inc. and UCB, Inc. Go to Neurology.org for full disclosures.

\section{REFERENCES}

1. Kono S. Aceruloplasminemia. Curr Drug Targets 2012;13: 1190-1199.

2. Schneider SA, Hardy J, Bhatia KP. Syndromes of neurodegeneration with brain iron accumulation (NBIA): an update on clinical presentations, histological and genetic underpinnings, and treatment considerations. Mov Disord 2012;27:42-53. 


\title{
Neurology
}

\author{
Teaching NeuroImages: Neurodegeneration with brain iron accumulation in \\ aceruloplasminemia \\ Natalie E. Parks, Robert A. Vandorpe and Jeremy J. Moeller \\ Neurology 2013;81;e151-e152 \\ DOI 10.1212/01.wnl.0000435557.21319.ad
}

This information is current as of November 11, 2013

\section{Updated Information \& Services \\ Supplementary Material \\ References \\ Subspecialty Collections}

Permissions \& Licensing

Reprints including high resolution figures, can be found at: http://n.neurology.org/content/81/20/e151.full

Supplementary material can be found at: http://n.neurology.org/content/suppl/2013/11/09/81.20.e151.DC1

This article cites 2 articles, 0 of which you can access for free at: http://n.neurology.org/content/81/20/e151.full\#ref-list-1

This article, along with others on similar topics, appears in the following collection(s):

All Cognitive Disorders/Dementia

http://n.neurology.org/cgi/collection/all_cognitive_disorders_dementia Basal ganglia

http://n.neurology.org/cgi/collection/basal_ganglia

MRI

http://n.neurology.org/cgi/collection/mri

Retina

http://n.neurology.org/cgi/collection/retina

Information about reproducing this article in parts (figures,tables) or in its entirety can be found online at:

http://www.neurology.org/about/about_the_journal\#permissions

Information about ordering reprints can be found online:

http://n.neurology.org/subscribers/advertise

Neurology ${ }^{\circledR}$ is the official journal of the American Academy of Neurology. Published continuously since 1951, it is now a weekly with 48 issues per year. Copyright @ 2013 American Academy of Neurology. All rights reserved. Print ISSN: 0028-3878. Online ISSN: 1526-632X.

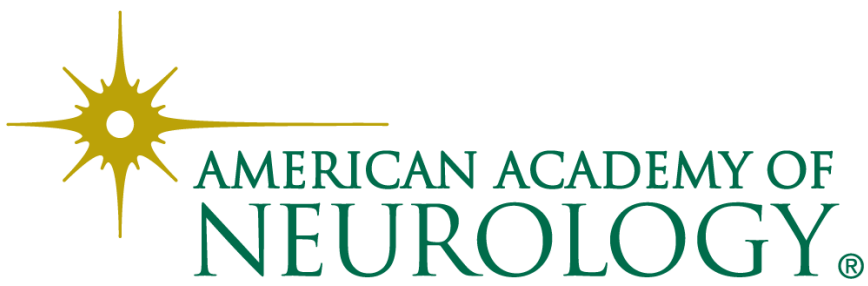

